\title{
Evaluation of Combination of Botanicals and Insecticides against Population Builds up of Cotton Whitefly (Bemisia tabaci, Gennadius) and Its Natural Enemies
}

\author{
S. Balabantaray ", R.S. Jaglan and K.K. Dahiya
}

Department of Entomology, College of Agriculture, CCSHAU, Hisar-125004, India

*Corresponding author

\begin{abstract}
A B S T R A C T
Keywords

Cotton, Whitefly, Natural enemies,

Pesticide combinations, $\mathrm{BC}$ ratio.

Article Info

Accepted:

20 March 2018

Available Online:

10 April 2018

To manage the population of cotton whitefly (Bemisia tabaci), an experiment was laid out in randomised block design (RBD) with nine treatments including untreated control and each treatment was replicated thrice. The study revealed that among nine treatments $\mathrm{T}_{8}$ (Neem Baan 1500 ppm@1.01/acre + thiamethoxam 25 WG @ 40 g/acre + Neem Baan 1500 ppm @ 1.0 1/acre) was better against whitefly, where the minimum population of adult whiteflies were found during $3^{\text {rd }}$ DAS (1.89 adults/leaf), $5^{\text {th }}$ DAS (1.78 adults/leaf) and $7^{\text {th }}$ DAS (2.11 adults/leaf) but $T_{1}$ was found safest to the natural enemies with 1.89 per plant natural enemies population and had highest $\mathrm{BC}$ ratio (1.17).
\end{abstract}

\section{Introduction}

Cotton (Gossypium spp.) belongs to the family "Malvaceae" and genus "Gossypium" popularly known as "White Gold" and "Natural Fiber" is a commercial crop of paramount importance. It is considered as the landmark achievement of any civilization as it provides clothing to human beings and gainful employment to millions of people in the field of agriculture and industry (Singhal, 2003).

In India cotton is cultivated on 11.87 million hectare with a production of 484 million bales of seed cotton (Anonymous, 2015). The average productivity of cotton in India is 537 kilogram lint per hectare which is low when compared to world average of 760 kilogram lint per hectare. India occupies 37.20 per cent of global cotton area contributing 25.58 per cent of world production. Thus India ranks first in area and production on global basis. Despite the large area, the productivity in India is very low (Patel et al., 2016). In Haryana, cotton crop is grown in five major districts viz., Hisar, Fatehabad, Jind, Bhiwani and Sirsa. The year 2015-16 was not congenial for cotton as both abiotic and biotic stresses pulled down the production as well as productivity in these areas. The total area under cotton was 6.03 lakh hectares and production was 15.00 lakh bales with 
productivity of 423 kilogram per hectare (Anonymous, 2015).

Amongst the cotton insect-pests, whitefly a sucking insect-pest has been reported as a major pest during mid to late cotton growing season causing 50 per cent damage due to loss of sap which ultimately reduces plant vigour.

The excessive and indiscriminate use of insecticides for the control of sucking pests has resulted in development of insecticide resistance to cypermethrin, acephate, chlorpyriphos, dimethoate, monocrotophos, oxydemeton methyl and quinalphos (Kumar and Grewal, 2014).

The management of Bemisia tabaci is challenging task as well as having ill-effects to human health and environment in the present day scenario upon using the insecticides for the control of the pest. Thus keeping in view the devastating effect of whitefly during 2015 in Punjab and Haryana the cotton growing states of North India, the present studies were undertaken with an aim to determine the best combination of safer pesticides to manage whitefly without harming the NEs.

\section{Materials and Methods}

The experiment was conducted during kharif season of 2016 at Research Area of Department of Entomology, CCS Haryana Agricultural University, Hisar. Experiment was laid out in randomised block design (RBD) with nine treatments including untreated control and each treatment was replicated three times (made into blocks) and denoted as B1, B2 and B3.

The American cotton variety H-1117 was used for the experiment which was sown on $7^{\text {th }}$ may 2016. The crop was sown by maintaining a spacing of $67.5 \mathrm{~cm} \times 30 \mathrm{~cm}$ in a plot size of 5 $\mathrm{m} \times 4 \mathrm{~m}$ with a block border of $1 \mathrm{~m}$ between replications and $30 \mathrm{~cm}$ bund between the plots. The experimental field was maintained according to the recommendation of "Package of Practices of Kharif crops" of CCS Haryana Agricultural University, Hisar (Anonymous, 2005). When the whitefly population reached economic threshold (ET) i.e. 6-8 adults per leaf, the crop was treated with the following treatments of bio rational pesticides thrice at 10 days intervals of each spray. Sprayings were done by employing a knapsack sprayer using hollow cone nozzle and the latter were held 0.3-0.5 meter above the cotton plants while spraying (Wu et al., 2002).

The crop was sprayed with an application rate of 200 litre water per acre. There were nine treatments including control, each of them consisted of different insecticides with their dosages as per the recommendation of the package of practices (Table 1).

Population of whitefly was recorded as per the method adopted under objective number one. Post treatment observations were recorded 1, 3,5 and 7 days after treatment. Then the observations were compared to conclude which is the most effective insecticide against whitefly and safest for their natural enemies.

\section{Results and Discussion}

\section{Effects of insecticides against adult whitefly population build up}

In each treatment three sprays were done at ten days interval and the data was taken one day before and on the $1^{\text {st }}, 3^{\text {rd }}, 5^{\text {th }}$ and $7^{\text {th }}$ DAS (days after spray). The " $\mathrm{T}_{9}$ " was taken as control having no insecticide treatment. The data in the Table 2 revealed that all the insecticides evaluated against the whitefly adults; less number of adult whiteflies was recorded as compared to control. There was no significant difference in the population of whitefly before applying the insecticides. 
Observation after first spray recorded on $1^{\text {st }}$ DAS (days after spray) revealed that minimum population of whitefly adults i.e. 1.11 per leaf was in treatment $T_{5}$ followed by $T_{4}(1.22$ adults/leaf). The minimum whitefly population found on $3^{\text {rd }}$ DAS i.e. 3 per leaf was in treatment $T_{4}$, which was found at par with the $\mathrm{T}_{3}$. Observation recorded on $5^{\text {th }}$ DAS revealed that minimum population of whitefly adults i.e. 4.78 per leaf was in treatment $\mathrm{T}_{5}$.

On the $7^{\text {th }}$ DAS observation of whitefly population was found minimum in $\mathrm{T}_{4}$ i.e. 7.67 per leaf. All the treatments had less population of whitefly than $\mathrm{T}_{9}$.

In the second spray there was change in sequence (as mentioned above) of the application of insecticides i.e. in $\mathrm{T}_{5}, \mathrm{~T}_{6}, \mathrm{~T}_{7}$ and $\mathrm{T}_{8}$. Observations on $1^{\text {st }}$ DAS revealed the minimum population in the $\mathrm{T}_{8} \quad(0.22$ adults/leaf) that was followed by $\mathrm{T}_{6}(0.33$ adults/leaf). The same trend of population build up was there in following days, where there was minimum population of adults found in $\mathrm{T}_{8}$ i.e. $3^{\text {rd }}$ DAS (1.89 adults/leaf), $5^{\text {th }}$ DAS (2.67 adults/leaf), $7^{\text {th }}$ DAS (7.55 adults/leaf). All the treatments had less population of whitefly than $T_{9}$. In the third spray there was again change in the insecticide sequence i.e. in $\mathrm{T}_{5}, \mathrm{~T}_{6}, \mathrm{~T}_{7}$ and $\mathrm{T}_{8}$. Observations on $1^{\text {st }} \mathrm{DAS}$ revealed the minimum population in the $T_{8}$ (0.67 adults/leaf) that was followed by $\mathrm{T}_{6}$ (0.89 adults/leaf). The same trend of population build up was there in following days, where there was minimum population of adults found in $\mathrm{T}_{8}$ i.e. $3^{\text {rd }}$ DAS $(1.89$ adults/leaf), $5^{\text {th }}$ DAS (1.78 adults/leaf), $7^{\text {th }}$ DAS (2.11 adults/leaf). There was effective control of whitefly adults in $\mathrm{T}_{8}$.

\section{Effects of insecticides against natural enemies' population of whitefly}

The data in Figure 1 indicate that up to some extent the natural enemies' population of whitefly especially the predators like lady bird beetles and their grubs, chrysoperla carnea grub and the spider are affected by all the chemical treatments applied against whitefly management. The natural enemies' population before insecticide spray was found to be differ numerically but not significantly. Among them the $T_{1}$ was found safest to the natural enemie's population which was followed by $\mathrm{T}_{5}$ and the harmful one was $\mathrm{T}_{4}$ which even destroyed the natural enemies' population completely.

Table.1 Different chemical treatments for management of whitefly on cotton

\begin{tabular}{|c|c|}
\hline & TREATMENTS: \\
\hline T1 & Nimbecidine300 ppm @1.01/acre \\
\hline $\mathbf{T 2}$ & Neem Baan1500 ppm@1.01/acre \\
\hline T3 & Thiamethoxam25 WG @40 g /acre \\
\hline T4 & Triazophos 40EC@600 ml/acre \\
\hline \multirow[t]{2}{*}{ T5 } & Nimbecidine 300 ppm @1.0 1/acre + Nimbecidine 300 ppm @ 1.0 1/acre + \\
\hline & Thiamethoxam25 WG@40g/acre \\
\hline \multirow[t]{2}{*}{ T6 } & Nimbecidine 300 ppm @1.01/acre + Thiamethoxam 25 WG @ 40 g /acre + \\
\hline & Nimbecidine300 ppm@1.0 1/acre \\
\hline \multirow[t]{2}{*}{ T7 } & Neem Baan 1500 ppm @1.0 1/acre + Neem Baan 1500 ppm @ 1.0 1/acre + \\
\hline & Thiamethoxam25 WG @ 40 g /acre \\
\hline \multirow[t]{2}{*}{ T8 } & Neem Baan 1500 ppm @ 1.0 1/acre + Thiamethoxam 25 WG @ $40 \mathrm{~g}$ /acre + Neem \\
\hline & Baan1500 ppm@1.01/acre \\
\hline T9 & Control \\
\hline
\end{tabular}


Table.2 Mean population of whitefly adults after spraying different insecticides at 10 days interval during khraif 2016 season

\begin{tabular}{|c|c|c|c|c|c|c|c|c|c|c|c|c|c|}
\hline \multirow{3}{*}{$\begin{array}{c}\text { Treatme } \\
\text { nts }\end{array}$} & \multirow{3}{*}{$\begin{array}{l}\text { Before } \\
\text { spray } \\
\left(24^{\text {th }}\right.\end{array}$} & \multirow[b]{3}{*}{$1^{\mathrm{st}}$} & & \multicolumn{8}{|c|}{ Whitefly adults population per leaf after 3 sprays at 10 days interval } & & \multirow[b]{3}{*}{$7^{\text {th }}$} \\
\hline & & & \multicolumn{2}{|c|}{$1^{\text {st }}$ spray } & \multirow[b]{2}{*}{$7^{\text {th }}$} & \multirow[b]{2}{*}{$1^{\text {st }}$} & \multicolumn{2}{|c|}{$2^{\text {nd }}$ spray } & \multirow[b]{2}{*}{$7^{\text {th }}$} & \multirow[b]{2}{*}{$1^{\text {st }}$} & \multicolumn{2}{|c|}{$3^{\text {rd }}$ spray } & \\
\hline & & & $3^{\mathrm{rd}}$ & $5^{\text {th }}$ & & & $3^{\text {rd }}$ & $5^{\text {th }}$ & & & $3^{\text {rd }}$ & $5^{\text {th }}$ & \\
\hline & Augus & DAS & DAS & DAS & DAS & DAS & DAS & DAS & DAS & DAS & DAS & DAS & DAS \\
\hline & t) & & & & & & & & & & & & \\
\hline \multirow[t]{2}{*}{$\mathrm{T}_{1}$} & 7 & 1.33 & 3.33 & 5.11 & 9.89 & 2.44 & 4 & 5.89 & 9.67 & 2.67 & 3.67 & 6.56 & 6.89 \\
\hline & $(2.825)$ & $(1.525)$ & (2.081) & $(2.471)$ & (3.298) & (1.855) & $(2.235)$ & $(2.625)$ & (3.265) & (1.914) & (2.157) & (2.748) & $(2.809)$ \\
\hline \multirow[t]{2}{*}{$\mathrm{T}_{2}$} & 7.45 & 2.33 & 4.22 & 6.45 & 10.11 & 1.89 & 3.22 & 5 & 9 & 2.22 & 3.33 & 5.11 & 5.67 \\
\hline & $(2.905)$ & $(1.824)$ & $(2.284)$ & $(2.728)$ & (3.330) & (1.698) & $(2.054)$ & $(2.449)$ & $(3.162)$ & $(1.792)$ & $(2.081)$ & $(2.472)$ & $(2.581)$ \\
\hline \multirow[t]{2}{*}{$\mathrm{T}_{3}$} & 7.22 & 3.33 & 3 & 6.22 & 10.78 & 3.33 & 3.11 & 6.11 & 11.11 & 3.44 & 2.78 & 6.89 & 7.44 \\
\hline & $(2.862)$ & $(2.081)$ & (1.995) & (2.687) & (3.431) & $(2.081)$ & (2.027) & (2.666) & (3.480) & (2.108) & (1.938) & (2.809) & $(2.906)$ \\
\hline \multirow[t]{2}{*}{$\mathrm{T}_{4}$} & 6.89 & 1.22 & 3 & 5.22 & 7.67 & 1.22 & 3.22 & 6.33 & 10.11 & 2.11 & 3.55 & 6.22 & 5.33 \\
\hline & (2.803) & (1.489) & (1.999) & $(2.493)$ & (2.943) & (1.489) & (2.054) & (2.708) & (3.332) & (1.753) & (2.133) & (2.687) & (2.516) \\
\hline \multirow[t]{2}{*}{$\mathrm{T}_{5}$} & 7.22 & 1.11 & 3.11 & 4.78 & 9.67 & 2.33 & 4.33 & 5.89 & 9.56 & 1.89 & 2.22 & 3 & 4.33 \\
\hline & (2.865) & (1.452) & (2.027) & $(2.401)$ & (3.265) & (1.824) & (2.309) & (2.625) & (3.246) & (1.692) & (1.794) & (1.999) & $(2.309)$ \\
\hline \multirow[t]{2}{*}{$\mathrm{T}_{6}$} & 8.11 & 1.25 & 3.45 & 5 & 9.89 & 0.33 & 2.11 & 3.56 & 8.11 & 0.89 & 2.11 & 2.89 & 3.11 \\
\hline & (3.014) & (1.493) & (2.107) & (2.449) & (3.299) & (1.149) & (1.761) & (2.132) & (3.018) & (1.365) & (1.761) & (1.972) & $(2.026)$ \\
\hline \multirow[t]{2}{*}{$\mathrm{T}_{7}$} & 7.33 & 2.33 & 4.11 & 6.33 & 10.33 & 1.44 & 3.44 & 4.11 & 9.11 & 1.33 & 2.33 & 3.44 & 4.78 \\
\hline & $(2.885)$ & $(1.824)$ & $(2.259)$ & $(2.449)$ & (3.366) & $(1.551)$ & $(2.108)$ & $(2.260)$ & (3.178) & $(1.525)$ & $(1.824)$ & (2.106) & $(2.404)$ \\
\hline \multirow[t]{2}{*}{$\mathrm{T}_{8}$} & 7.22 & 2.22 & 4.33 & 6.56 & 10.22 & 0.22 & 1.89 & 2.67 & 7.55 & 0.67 & 1.89 & 1.78 & 2.11 \\
\hline & (2.866) & (1.794) & (2.309) & $(2.748)$ & (3.350) & (1.102) & (1.694) & (1.911) & $(2.923)$ & (1.276) & (1.699) & (1.664) & $(1.761)$ \\
\hline \multirow[t]{2}{*}{$\mathrm{T}_{9}$} & 7.22 & 7.11 & 7.67 & 8.33 & 12.22 & 7.22 & 7.89 & 8.56 & 11.45 & 7.44 & 7.89 & 8.56 & 7.33 \\
\hline & (2.862) & (2.845) & (2.943) & (3.054) & (3.636) & (2.866) & (2.980) & (3.091) & (3.527) & (2.905) & (2.980) & (3.091) & $(2.884)$ \\
\hline $\mathrm{SE}(\mathrm{m}) \pm$ & (0.104) & $(0.051)$ & $(0.049)$ & $(0.055)$ & $(0.065)$ & $(0.073)$ & $(0.050)$ & $(0.050)$ & $(0.061)$ & $(0.088)$ & $(0.067)$ & (0.049) & $(0.041)$ \\
\hline $\mathrm{CD}$ & (N.S) & $(0.155)$ & $(0.147)$ & $(0.166)$ & $(0.197)$ & $(0.222)$ & $(0.152)$ & $(0.152)$ & $(0.184)$ & $(0.266)$ & $(0.202)$ & (0.149) & (0.124) \\
\hline$(\mathrm{P}=0.05)$ & & & & & & & & & & & & & \\
\hline
\end{tabular}


Fig.1 Population of whitefly natural enemies/plant after spray of different insecticide

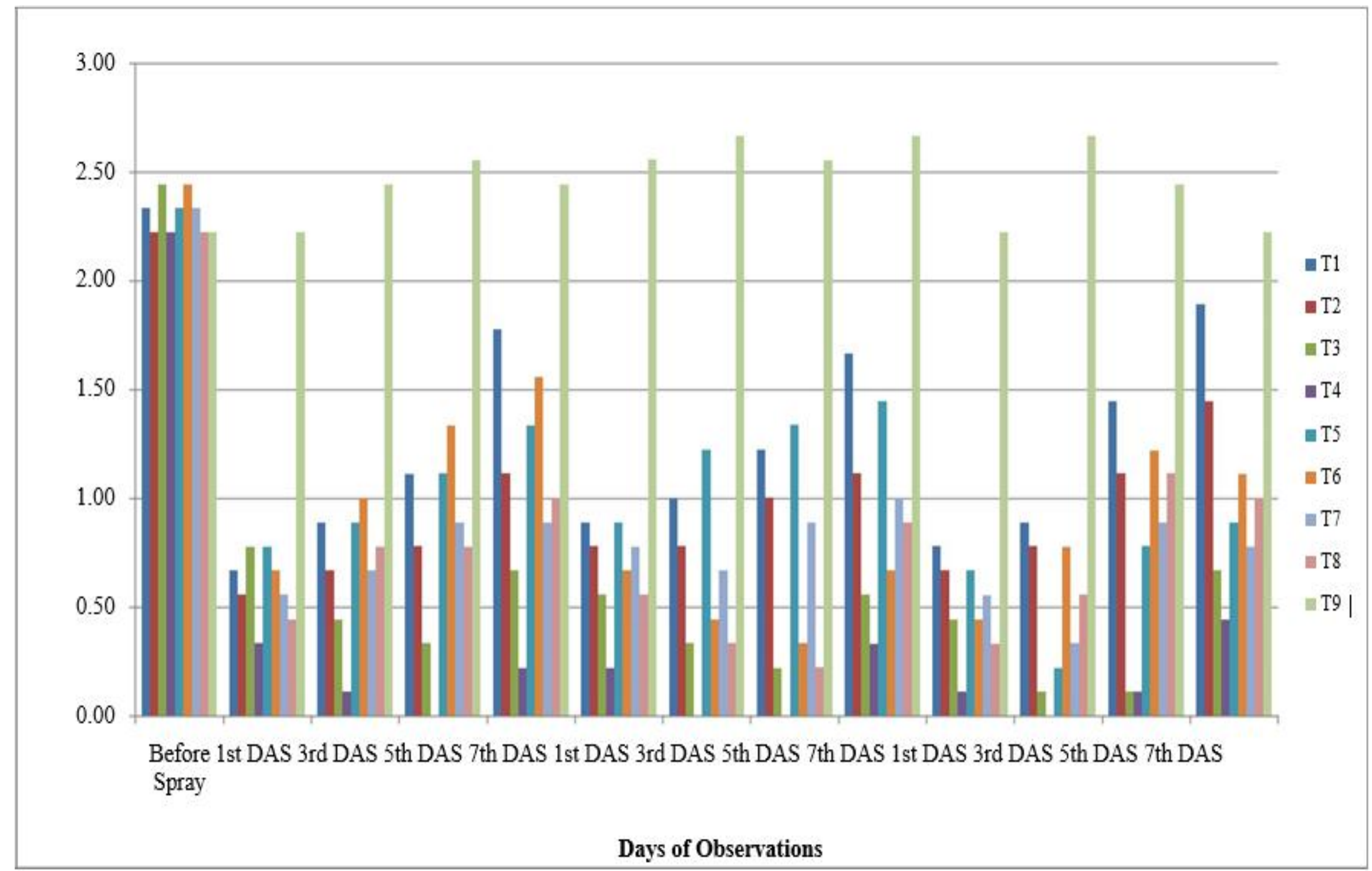


Table.3 Benefit cost ratio of cotton after whitefly management by various treatments

\begin{tabular}{|c|c|c|c|c|c|c|c|c|}
\hline \multirow{2}{*}{\multicolumn{4}{|c|}{\begin{tabular}{|l|l|} 
Input & \\
Nimbecidine $300 \mathrm{ppm}(2.5 \mathrm{l} / \mathrm{ha})$
\end{tabular}}} & & \multicolumn{2}{|l|}{ Cost } & & \\
\hline & & & & & \multicolumn{2}{|c|}{ Rs. $280 / 1$} & & \\
\hline \multicolumn{4}{|c|}{ Neem Baan 1500 ppm (2.5 1/ha) } & & \multicolumn{2}{|c|}{ Rs. 383/1 } & & \\
\hline \multicolumn{3}{|c|}{ Thiamethoxam $25 \mathrm{WG}$} & $(0.1 \mathrm{Kg} / \mathrm{ha})$ & & \multicolumn{2}{|c|}{ Rs. $1510 / \mathrm{Kg}$} & & \\
\hline \multicolumn{3}{|c|}{ Triazophos 40 EC (1.5 l/ha) } & & & \multicolumn{2}{|c|}{ Rs. 390/1 } & & \\
\hline \multicolumn{2}{|c|}{ Labour charge } & & & & \multicolumn{3}{|c|}{ Rs. 350/one man day } & \\
\hline \multicolumn{3}{|c|}{ Market Price of Cotton } & & & \multicolumn{2}{|c|}{ Rs. $5000 / \mathrm{q}$} & & \\
\hline \multicolumn{2}{|c|}{ Price of by products } & & & & \multicolumn{2}{|c|}{ Rs. $188 / \mathrm{q}$ of cotton } & & \\
\hline \multicolumn{2}{|c|}{ Harvesting Charge } & & & & \multicolumn{2}{|c|}{ Rs. $850 / q$ of cotton } & & \\
\hline \multirow[t]{3}{*}{ 高 } & \multirow{2}{*}{ Yield } & \multirow[t]{2}{*}{ 高 } & \multirow[t]{2}{*}{ 衰 } & \multirow[t]{2}{*}{ 育 } & \multirow[t]{2}{*}{ 峞 } & \multirow[t]{3}{*}{$\stackrel{\mathscr{E}}{\mathscr{E}}$} & \multirow{2}{*}{$\begin{array}{c}\text { B:C ratio } \\
\text { cost } \\
\text { over }\end{array}$} & \multirow{2}{*}{$\begin{array}{l}\text { B:C ratio } \\
\text { over total }\end{array}$} \\
\hline & & & & & & & & \\
\hline & q/ha & & & & & & variable & cost \\
\hline $\mathbf{T}_{1}$ & 20.12 & 53183 & 89570 & 104375 & 51193 & 14805 & 1.96 & 1.17 \\
\hline $\mathbf{T}_{2}$ & 20.23 & 54083 & 90650 & 104875 & 50793 & 14225 & 1.94 & 1.16 \\
\hline $\mathbf{T}_{\mathbf{3}}$ & 18.45 & 49910 & 85643 & 96000 & 46090 & 10358 & 1.92 & 1.12 \\
\hline $\mathbf{T}_{4}$ & 18.87 & 52135 & 88315 & 98125 & 45990 & 9810 & 1.88 & 1.11 \\
\hline $\mathbf{T}_{\mathbf{5}}$ & 19 & 51568 & 87633 & 98750 & 47183 & 11118 & 1.91 & 1.13 \\
\hline $\mathbf{T}_{6}$ & 19.23 & 51775 & 87883 & 99875 & 48100 & 11993 & 1.93 & 1.14 \\
\hline $\mathbf{T}_{7}$ & 19.12 & 52220 & 88418 & 99375 & 74155 & 10958 & 1.90 & 1.12 \\
\hline $\mathbf{T}_{8}$ & 19.45 & 52523 & 88778 & 101000 & 48478 & 12223 & 1.92 & 1.14 \\
\hline$T_{9}$ & 16.77 & 46715 & 81808 & 87633 & 40918 & 5825 & 1.88 & 1.07 \\
\hline$* \mathrm{RO}$ & turns ov & r Varic & $\cos t$ & & *RO7 & Irn & Total cos & \\
\hline
\end{tabular}

Among the various treatments the maximum $\mathrm{BC}$ ratio (1.17) was obtained from $\mathrm{T}_{1}$ (nimbecidine 300 ppm @ 11/acre, three sprays at 10 days intervals) which was followed by (1.16) in $\mathrm{T}_{2}$ (Neem Baan 1500 ppm @ 11/acre, three sprays at 10 days intervals) and (1.14) in $\mathrm{T}_{8}$ (Neem Baan 1500 ppm @ $1.01 /$ acre + thiamethoxam 25 WG @ 40 g/acre + Neem Baan 1500 ppm @ 1.0 1/acre) (Table 3). The present findings revealed that according to population reduction aspect the control of both nymphs and adults of whitefly were better in case of $\mathrm{T}_{8}$ (Neem Baan 1500 ppm @ 1.0 1/acre + thiamethoxam 25 WG @ 40 g/acre + Neem Baan 1500 ppm @ 1.0 1/acre) as compare to other treatments. However, the maximum yield was obtained in nimbecidine 300 ppm@11/acre treated plots hence, the 
$\mathrm{BC}$ ratio. The results are similar to that of Saini (2014) who reported that spray of NSKE 5 per cent alternated with ethion and novaluron were the most effective treatments combination in controlling whitefly adult population on mungbean crop. However, the maximum yield was obtained in nimbecidine $(5 \mathrm{ml} / \mathrm{l})$ treated plots followed by two times NSKE 5 per cent treated plots. The results are in confirmation with Naik et al., (2009) who indicated that besides recording higher fruit yield, thiamethoxam @ $0.005 \%$ and combination treatments of thiamethoxam @ $0.0025 \%+$ novaluron @ $0.05 \%$ and thiamethoxam@0.0025\% + azadirachtin@ $0.15 \%$ were highly effective in reducing the population of Bemisia tabaci and Amrasca biguttula biguttula on brinjal.

The present study revealed that the $T_{1}$ (nimbecidine 300 ppm @ 11/acre) and $\mathrm{T}_{2}$ (Neem Baan 1500 ppm @ 11/acre) are safest for the natural enemies of whitefly, which was followed by $\mathrm{T}_{8}$ (Neem Baan 1500 ppm @ 1.0 1/acre + thiamethoxam 25 WG @ 40 g/acre + Neem Baan 1500 ppm @ 1.0 1/acre). The findings are similar with Kharche et al., (2015) who revealed that the soil application of carbofuran 3G @ $5 \mathrm{~kg} / \mathrm{ha}$ (T1), soil application of thiamethoxam 75SG @75 g a.i./ha (T2), soil application of imidacloprid 70WS @ 110 g a.i./ha (T3) proved significantly safer treatments which recorded $1.53,1.27,1.06$ and 1.06 number of lady bird beetle/plant, respectively than all other insecticidal treatments.

The result inferred that few selective ecofriendly insecticides are safer to the natural enemies of whitefly as compared to other conventional insecticides.

Under whitefly management trial, the better result was found in case of $\mathrm{T}_{8}$ (Neem Baan 1500 ppm @ 1.0 1/acre + thiamethoxam 25 WG @ 40 g/acre + Neem Baan 1500 ppm @
$1.0 \mathrm{l} / \mathrm{acre}$ ), so this combination of pesticide can be utilized for management of whitefly in cotton.

Maximum BC ratio (1.17) was obtained from $\mathrm{T}_{1}$ (nimbecidine 300 ppm @ 11/acre, and that was found safer to the NEs.

\section{Acknowledgments}

I am thankful to Department of Entomology, College of Agriculture, CCSHAU for conducting my experiment. I am also thankful to my guide Dr. R. S. Jaglan and co-guide Dr. K. K. Dahiya for their guidance and for their sincere efforts; I am able to successfully complete my research work.

\section{References}

Anonymous (2005). Package of Practice of Kharif crop. Directorate of publication. CCS HAU, Hisar.

Anonymous (2015). All India Area, production and Yield of Cotton. Agricultural Statistics, Ministry of Agriculture, Government of India, New Delhi.

Anonymous (2015). Annual Report, (201415). All India coordinated Cotton Improvement Project (Indian Council of Agricultural Research), Central Institute for Cotton Research, Coimbatore641003.

Kharche, R. S. et al., (2015). Bio-efficacy of new insecticides against natural enemies of Cotton. Annals of Plant Protection Sciences, 23(2): 390-417.

Kumar, V. and Grewal, G. K. (2014). Relative toxicity of different insecticides to Bemisia tabaci (Gennadius) on cotton in Punjab. Pesticide Research Journal, 26(1): 48-55.

Naik, V. C. B. et al., (2009). Seasonal incidence and management of Bemisia tabaci Gennadius and Amrasca 
biguttula biguttula Ishida of brinjal. Annals of Plant Protection Sciences, 17(1): 9-13.

Patel, M. L. et al., (2016). Influence of abiotic factors on population dynamics of sucking insect pests in transgenic cotton. Advances in Life Sciences, 5(5): 1871-1875.

Saini, R. (2014). Varietal evaluation and management of whitefly, Bemisia tabaci (Gennadius) in urdbean, Vigna mungo (L.) Hepper. M. Sc. Thesis submitted to CCS Haryana Agricultural University, Hisar. pp. 42.

Singhal, V. (2003). Indian Agriculture, pp 215-29. Indian Economic Data Research Centre, New Delhi.

Wu, K. et al., (2002). Seasonal abundance of the mirids, Lygus lucorum and Adelphocoris spp. (Hemiptera: Miridae) on $B t$ cotton in northern China. Crop Protection, 21: 997-1002.

\section{How to cite this article:}

Balabantaray, S., R.S. Jaglan and Dahiya, K.K. 2018. Evaluation of Combination of Botanicals and Insecticides against Population Builds up of Cotton Whitefly (Bemisia tabaci, Gennadius) and Its Natural Enemies. Int.J.Curr.Microbiol.App.Sci. 7(04): 2436-2443.

doi: https://doi.org/10.20546/ijcmas.2018.704.280 